\title{
INFLUENCE OF LANDFILL METHANE EMISSIONS ON ENVIRONMENT - DISTRIBUTION MODELLING AND ASSESSMENT
}

\author{
BOGDANA VUJIĆa, NEMANJA STANISAVLJEVIC ${ }^{b}$, \\ FRANCISC POPESCUc, NIKOLINA TOSIC ${ }^{b}$, UNA MARČETA ${ }^{a}$, \\ MARJANA PARDANJAC ${ }^{a}$, VASILE PODE $^{d}$
}

\begin{abstract}
Landfilling practice in countries with waste management in transition is associated with non-controlled landfill gas and leachate emission. This practice requires sanitary landfill operations and remediation of unsanitary landfills as a prerequisite to join European Union. In order to get first insights on methane distributions for subsequent risk assessment model, this research, assess methane behavior patterns after emissions in the ambient air on environment from the controlled landfill site in Novi Sad, Republic of Serbia. Methane emission rate was assessed and crosschecked using landfill gas emissions model (LandGEM). The ADMS Mapper was used for the 3D simulation of the real environment of research field, including the complex structure of the landfill body and surrounding area. For simulation of methane dispersion into atmosphere, advanced Gaussian dispersion model ADMS Urban was applied. After processing and synthesis of the meteorological data, and defining the emission potential, simulations of the methane dispersion under different meteorological conditions (wind speed and direction, atmospheric temperature, humidity, pressure and cloud cover) were performed. As a result, methane distribution pattern was noted, several most unfavorable meteorological conditions and scenarios of methane distribution were assessed, and most vulnerable zones and locations influenced by the landfill methane emissions were identified.
\end{abstract}

Keywords: Methane emission, Air dispersion, Modelling, LandGem, ADMS urban, Serbia

a University of Novi Sad, Technical Faculty „Mihajlo Pupin “, Zrenjanin, Serbia

b University of Novi Sad, Faculty of Technical Sciences, Department of Environmental Engineering, Novi Sad, Serbia

c University Politehnica Timisoara, Faculty of Mechanical Engineering, Environmental Engineering, Timisoara, Romania

d University Politehnica Timisoara, Faculty of Industrial Chemistry and Environmental Engineering, Timisoara, Romania

* Corresponding author: bogdana.vujic@tfzr.rs 
BOGDANA VUJIĆ, NEMANJA STANISAVLJEVIC, FRANCISC POPESCU, NIKOLINA TOSIC,

UNA MARČETA, MARJANA PARDANJAC, VASILE PODE

\section{INTRODUCTION}

The Republic of Serbia is a European Union (EU) candidate country which needs to fulfill the requirements of the EU waste management directives, as a prerequisite for EU membership. One of the most important tasks is to eliminate non-compliant landfilling and to minimize and control emissions from existing waste disposal sites. There are 160 controlled and 3500 uncontrolled waste disposal sites in Serbia [1,2]. Controlled waste disposal sites do not meet sanitary-technical and technological standards (no liner systems, leachate and landfill gas collection). The Latest data indicates that only $30 \%$ of totally generated municipal solid waste (MSW) in Serbia is landfilled on sanitary landfills [2].

Uncontrolled landfilling has a huge impact on environment due to the complex chemical reactions during the waste decomposition process that yield in landfill gas (LFG) production. One of the basic problems is LFG which is dominantly composed out of methane $\left(\mathrm{CH}_{4}: 55-60 \% \mathrm{v} / \mathrm{v}\right)$ and carbon dioxide $\left(\mathrm{CO}_{2}: 40-45 \% \mathrm{v} / \mathrm{v}\right)$ that are identified as greenhouse gases $(\mathrm{GHG})$. Representative chemical processes of waste degradation in landfills could be described as follows:

a) Acetogenesis: $\quad \mathrm{C}_{6} \mathrm{H}_{12} \mathrm{O}_{6} \rightarrow 2 \mathrm{C}_{2} \mathrm{H}_{5} \mathrm{OH}+2 \mathrm{CO}_{2}$

b) Methanogenesis: $\mathrm{CH}_{3} \mathrm{COOH} \rightarrow \mathrm{CH}_{4}+\mathrm{CO}$

$$
\mathrm{CO}_{2}+4 \mathrm{H}_{2} \rightarrow \mathrm{CH}_{4}+2 \mathrm{H}_{2} \mathrm{O}
$$

However, quantitative data on LFG emissions from landfills in Serbia are scarce. There have been several attempts to quantify emissions $[1,3,4]$ but no specific reliable data exist for majority of location. Particularly, methane distribution in the ambient air has never been modelled neither quantified although it has 28 times greater global warming potential than $\mathrm{CO}_{2}$.

Where long-term landfill emission data are not available, different estimation models are used [5]. Intergovernmental Panel on Climate Change (IPCC) [6] model is commonly used for assessment of statewide emissions and United States Environmental Protection Agency's, LandGEM is used for specific sites and statewide. Both models are widespread models for prediction and estimation of methane production from landfills. For distribution in the environment, mathematical models are used for calculating the concentration of pollutants in the atmosphere $[7,8]$. Due to the uncertainties and complexities associated with the methane production and transport process, there are various researches based on methane emission assessment using mathematical models [9-10]. 
After being emitted into the atmosphere from the landfill, methane becomes the subject of numerous complex atmospheric chemical reactions which eventually produce ozone (Figure 1) [11].

However, in the lowest troposphere meteorological conditions can have diverse influence on methane distribution in the ambient air before its transformations [12]. Understanding distribution and influence of meteorological parameters on methane in ambient air can significantly contribute to human health risk avoidance and environmental quality due to uncontrolled methane emissions $[13,14]$.

The aim of this paper is to generate the preliminary data on influence of different meteorological conditions on methane distribution in the ambient air for controlled municipal landfill in Novi Sad, the Republic of Serbia. In lack of appropriate data this research could be the starting point for risk assessment and landfill remediation prioritization models in the developing and transition countries. Hence, the accent was not on the approach for estimating landfill gas emissions, but on the evaluation of the methane dispersion from a single local source in the atmosphere/ambient air under different meteorological parameters.

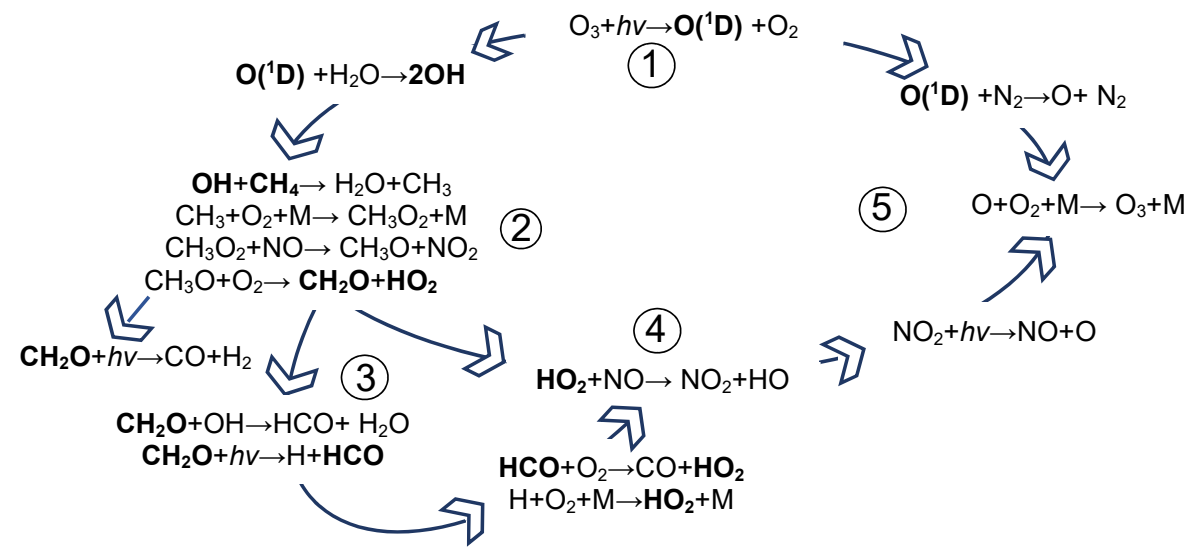

Figure 1. Atmospheric methane transformation. Methane transformations happen in presence of hydroxyl radicals $(\mathrm{OH})$ which stem from ozone $\left(\mathrm{O}_{3}\right)$ and UV light (hv) (1). Acetaldehyde $\left(\mathrm{CH}_{2} \mathrm{O}\right)(3)$ and hydroxyl radical $\left(\mathrm{HO}_{2}\right)$ (4) are formed in the reactions of $\mathrm{OH}$ radicals and $\mathrm{CH}_{4}(2)$ in presence of $\mathrm{NO}$ (4) which lead to the final product- ozone (5). ( $\mathrm{M}$ could be $\mathrm{N}_{2}, \mathrm{O}_{2}$ or any other molecule which by collision stabilizes $\mathrm{O}_{3}$ ).

\section{RESULTS AND DISCUSSION}

Results indicate that in 2017. 300 and $274 \mathrm{gs}^{-1}$ of methane were emitted from the landfill in Novi Sad for 1960 and 1970 respectively. 
BOGDANA VUJIĆ, NEMANJA STANISAVLJEVIC, FRANCISC POPESCU, NIKOLINA TOSIC,

UNA MARČETA, MARJANA PARDANJAC, VASILE PODE

The emission factors (EF) with higher value which refer to 1960 are adopted as an input for distribution modelling (Table 1).

Since the modelling using EF1 0.1 indicated the highest level of concentrations, this emission factor was used for further simulations.

Table 1. Potential methane flux from the landfill in Novi Sad

\begin{tabular}{|l|c|c|c|c|}
\hline \multirow{2}{*}{ Initial year of waste disposal/landfill operation } & \multirow{2}{*}{ Unit } & \multicolumn{3}{|c|}{ Oxidation factors } \\
\cline { 3 - 5 } & & 0.1 & 0.2 & 0.5 \\
\hline 1960 (EF1) & \multirow{2}{*}{$\mathrm{g} \mathrm{s}^{-1}$} & 300 & 234 & 167 \\
\cline { 3 - 5 } & & 274 & 213 & 152 \\
\hline
\end{tabular}

\section{Modelling results for the summer}

The long-term (LT) modelling using hourly meteorological data for the summer with vertical intersections at 7 points as well as spatial distribution in several receptors was performed. Methane concentrations were modelled using both emission factors (EF1 and EF2) with oxidation factors of $0.1,0.2$ and 0.5. Depending on the emission and oxidation factors, methane concentrations ranged from 62 to $1989 \mu^{-3}$ at the landfill ground level. The highest methane concentration in ambient air was modelled using EF1 with oxidation factor 0.1 (EF1 0.1) (see Table 2). Concerning the vertical distribution, modelled concentration levels slightly decreased with higher altitudes (up to $25 \mathrm{~m}$ ). However, modelled concentrations rapidly decreased above $25 \mathrm{~m}$. For instance, for EF1 0.1 at $33 \mathrm{~m}$ altitude methane concentration was $1141 \mu \mathrm{g} \mathrm{m}^{-3}$ while at altitudes above $50 \mathrm{~m}$ concentration was $159 \mu^{-3} \mathrm{gm}^{-3}$ (Table 2).

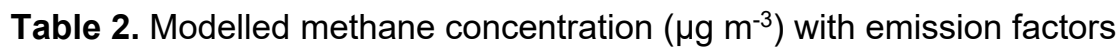
EF1 and EF2 at different atmospheric height ( $\mathrm{H}$ in meters)

\begin{tabular}{|c|c|c|c|c|c|c|c|}
\hline \multirow{2}{*}{$\mathbf{C}_{\text {metahne }} \mathbf{( g g m}^{-\mathbf{3}}$ ) } & \multicolumn{7}{|c|}{$\mathbf{H} \mathbf{( m )}$} \\
\cline { 2 - 8 } & 0 & 8 & 17 & 25 & 33 & 42 & 50 \\
\hline EF1 0.1 & 1989 & 1933 & 1876 & 1738 & 1141 & 291 & 159 \\
\hline EF1 0.2 & 1119 & 1087 & 1055 & 977 & 642 & 163 & 89 \\
\hline EF1 0.5 & 62 & 60 & 59 & 54 & 36 & 9 & 5 \\
\hline EF2 0.1 & 1269 & 1232 & 1195 & 1106 & 727 & 191 & 106 \\
\hline EF2 0.2 & 1022 & 993 & 964 & 893 & 586 & 149 & 81 \\
\hline EF2 0.5 & 567 & 551 & 535 & 495 & 325 & 83 & 45 \\
\hline
\end{tabular}


The spatial methane distribution indicated that the most vulnerable areas were located in the northwest (Industry 1), east (Road 1) and northeast from the landfill (Village 1 and Village 2). In this modelling iteration, methane dispersion was not recorded at ground level in the direction of populated area (Houses 1 and Houses 2), and shopping mall (Figure 2). The zone of spatial methane dispersion was determined by modelling through additional receptors: Industry 2, Village 11 and Road 2 (Table 3). In the dominant wind direction, modelled concentrations at additional receptors show the tendency of gradual decrease at the ground level. The zone of maximum methane concentration on the ground level is located at distances of up to $300 \mathrm{~m}$ from the landfill in the dominant wind directions.

This modelling iteration has identified several key patterns in methane distribution according to the prevailing meteorological conditions. Firstly, methane distribution is favorable at higher atmospheric layers. This fact is confirmed by the modelled concentrations in previously identified zones without significant methane impact on the ground level. However, in the zones Shopping mall, Houses 1 and Houses 2, at the altitude of $0 \mathrm{~m}$ these zones were not affected (Figure 2), while at $25 \mathrm{~m}$, modelled methane concentrations varied from $46 \mathrm{\mu gm}^{-3}$ to $131 \mathrm{\mu gm}^{-3}$. Similar patterns of increased methane dispersion in higher atmospheric layers were also reported by Soporanet al. [11].

Distribution of methane at different altitudes are presented in Figure 2 and Figure 3.

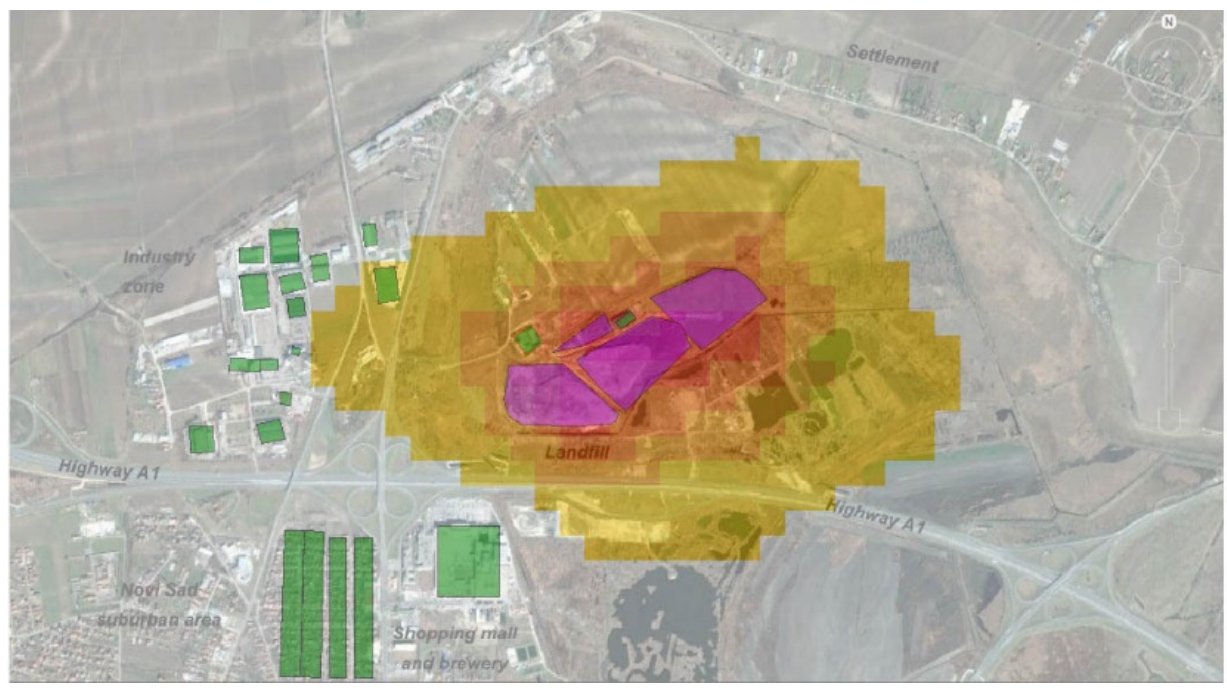

Figure 2. Modelled methane concentration $\mathrm{H}=0 \mathrm{~m}$ 


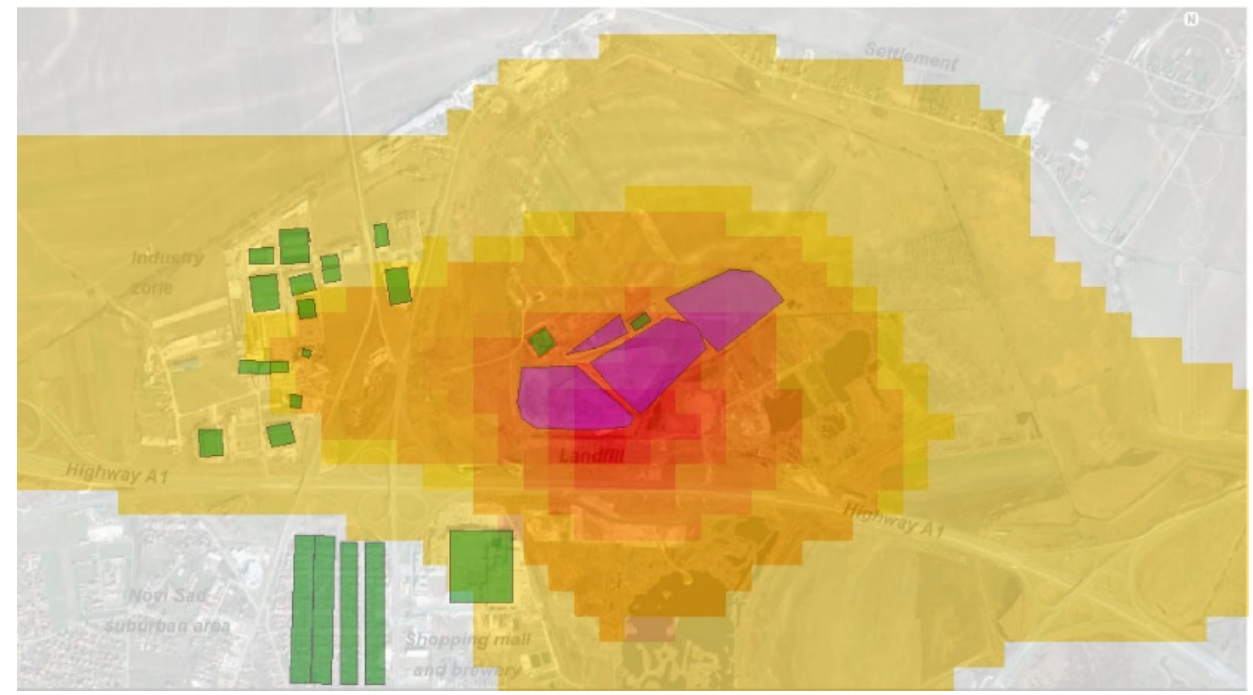

Figure 3. Modelled methane concentration at $\mathrm{H}=25 \mathrm{~m}$

Although the methane concentration contour plot showed that methane distribution improved on higher altitudes, numerical output confirmed that the modelled methane concentrations at distances larger than $400 \mathrm{~m}$ from the landfill were relatively constant and below $100 \mathrm{\mu g} \mathrm{m}^{3}$ at all modeling altitudes. Even though vertical methane distribution has improved to the certain height, the maximum concentrations were still calculated at the distances less than $300 \mathrm{~m}$ from the landfill.

\section{Modelling results for different scenarios}

To identify the most critical meteorological conditions that are favorable for improved methane dispersion, long-term modelling for specific scenarios (S1-S3) was performed. Methane concentrations in different meteorological scenarios indicated the same pattern as patterns modelled with hourly meteorological data for the whole summer. For all three scenarios the maximum methane concentrations were observed for EF1 0.1 as well. However, compared to modelling of S3, in S1 and S2, higher methane concentrations were observed. The methane dispersion on the ground level $(\mathrm{H}=0)$ for $\mathrm{S} 1$ and $\mathrm{S} 3$ is shown in the Figure 4 and Figure 5.

The maximum methane concentrations of $2686 \mathrm{\mu gm}^{-3}$ were modelled in $\mathrm{S} 1$ just above the ground level of the landfill. Lower concentrations of 2358 $\mathrm{\mu gm}^{-3}$ were obtained in scenario $\mathrm{S} 2$, while the lowest concentration was generated for S3 $\left(1082{\mu g m^{-3}}^{-3}\right.$. 
The first scenario (S1) vulnerable area is relatively small and limited

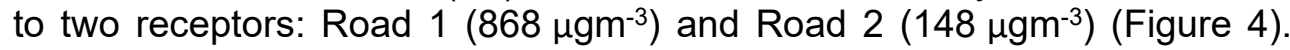
Methane distribution in S1 is similar to S2, but modelled concentrations in S2 were lower: in Road 1 modelled concentration was $357 \mu \mathrm{gm}^{-3}$, while in Road 2 was $132 \mathrm{\mu gm}^{-3}$. Opposite of S1 and S2, in S3, affected area included west oriented receptors, Industry 1 and Industry 2, where modelled methane

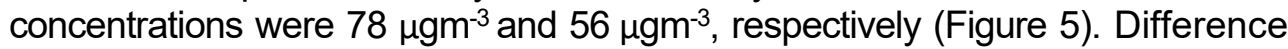
in modelled concentration levels between scenarios revealed the meteoritical conditions were favorable for methane distribution. Meteorological conditions, in S1 and S2, which contribute to higher methane concentration were characterized by relatively low wind speed (up to $2.4 \mathrm{~m}$ ) and high cloudiness (5-8 octas). The same patterns were observed by Garcia et al. [15].

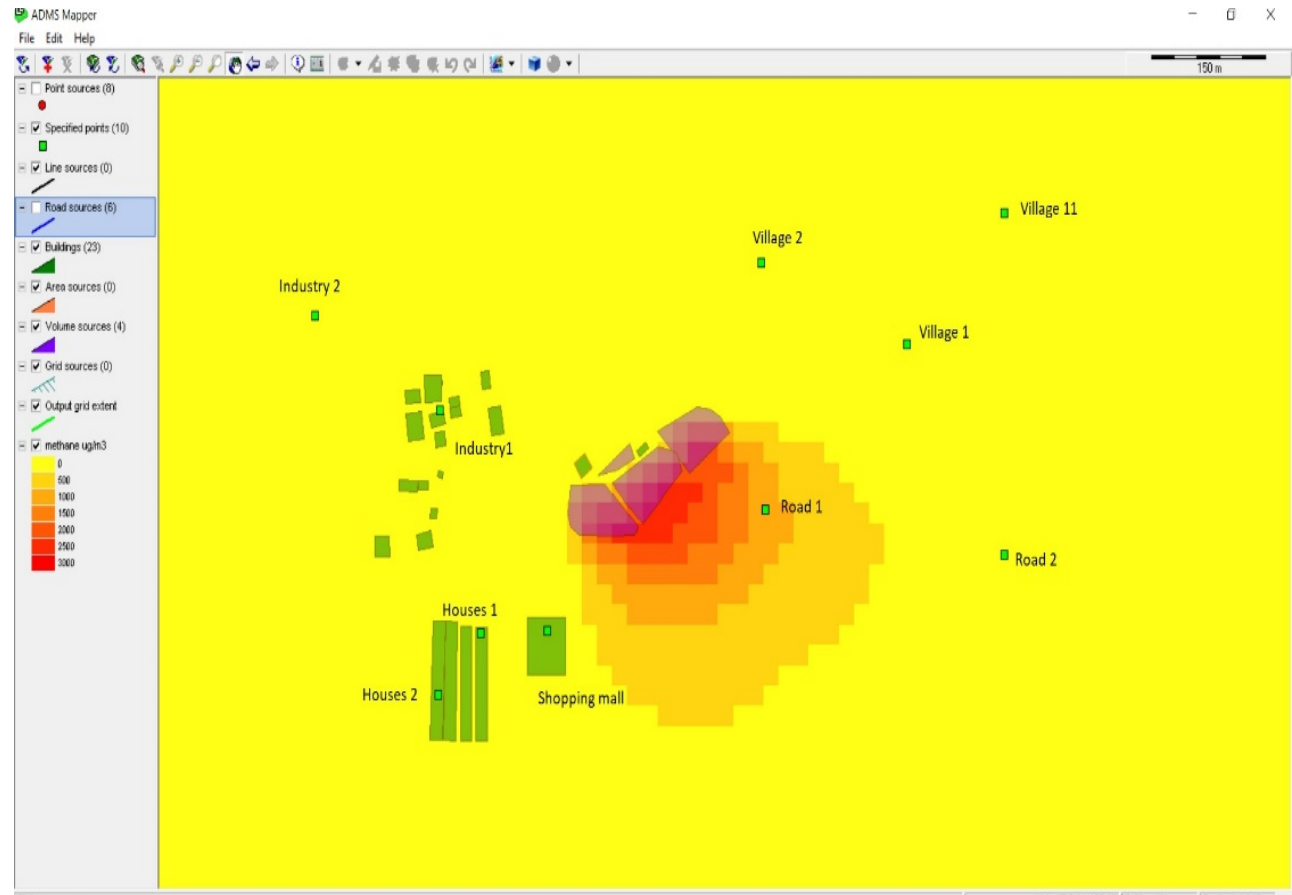

Figure 4. Methane dispersion at $\mathrm{H}=0 \mathrm{~m}$ (simulation for $\mathrm{S} 1$ using $\mathrm{EF} 10.1$ )

The spatial methane distribution identified through specific receptors indicated that the maximum methane concentrations at ground level were present at distances of up to $150 \mathrm{~m}$ from the landfill in the direction of the dominant air currents (obtained with hourly meteorological data). This is how concentrations in the range from $154 \mathrm{\mu g} \mathrm{m}^{-3}$ to $440 \mathrm{\mu g} \mathrm{m}^{-3}$ were modelled at the distance less than $300 \mathrm{~m}$ from the landfill depending on the location of the receptors. 
BOGDANA VUJIĆ, NEMANJA STANISAVLJEVIC, FRANCISC POPESCU, NIKOLINA TOSIC, UNA MARČETA, MARJANA PARDANJAC, VASILE PODE

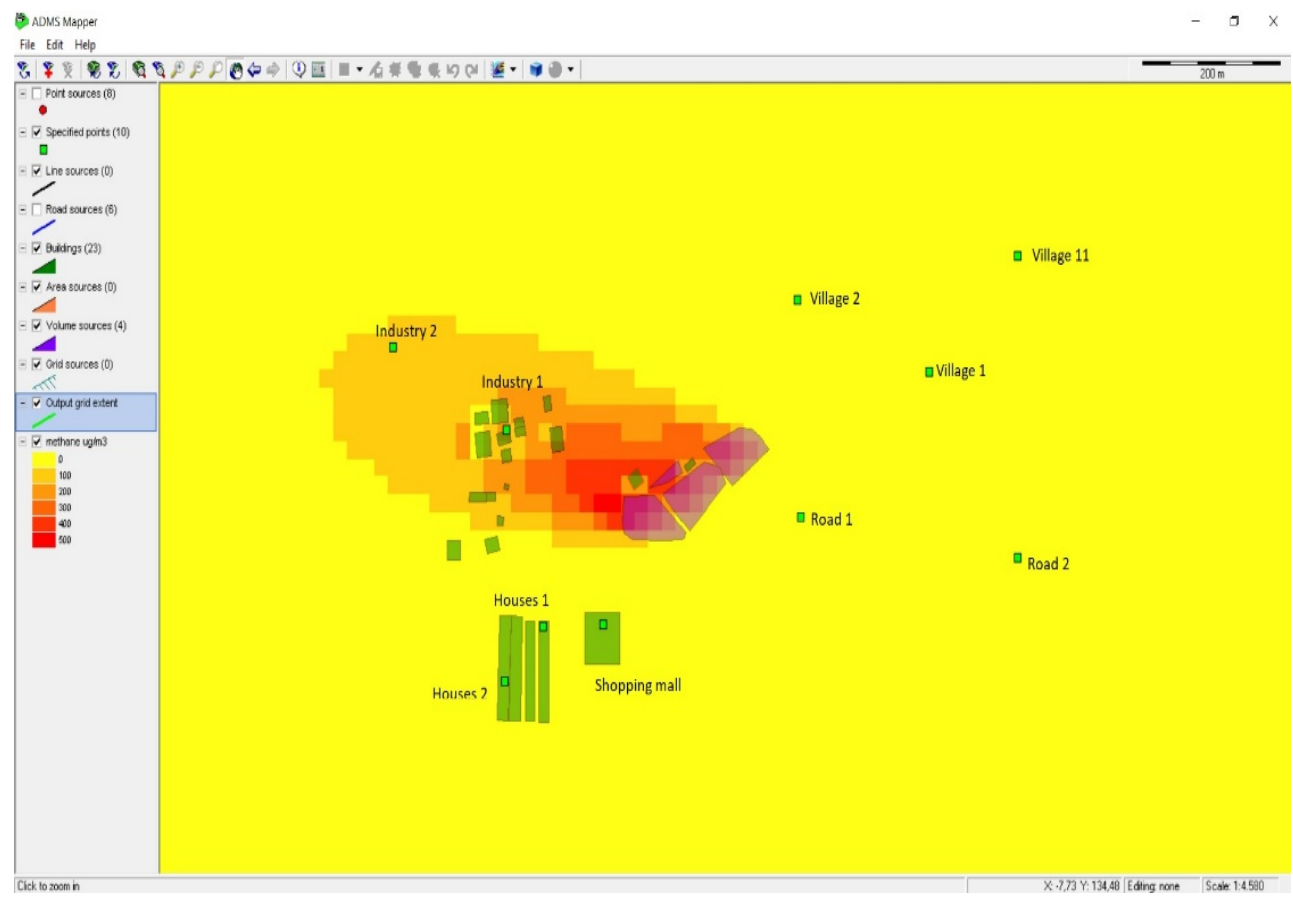

Figure 5. Methane dispersion at $\mathrm{H}=0 \mathrm{~m}$ (simulation for $\mathrm{S} 3$ using $\mathrm{EF} 10.1$ )

When it comes to different meteorological scenarios, the spatial methane distribution at ground level indicated that the maximum concentrations were found at the distances less than $200 \mathrm{~m}$ from the landfill. However, at $500 \mathrm{~m}$ distance, the concentrations modelled in scenarios were higher compared to the modelling for the entire summer. The highest modelled concentrations of $194 \mathrm{\mu gm}^{-3}$ were obtained in S1, at $550 \mathrm{~m}$ from the landfill in the direction of the dominant winds (Figure 6).

There is no defined limit value for methane in ambient air. Exemption is very high concentration of $500000 \mathrm{ppm}$ that can cause asphyxiation. Hence, the modelled concentrations were compared to the concentration in recently published studies. Using different mathematical models some authors reported the modelled concentration of methane in ambient air in the range from 12 - 4259 ppm [11,16]. However, the measurement conducted in the three cities of Romania, recorded concentration of ambient methane ranging from 2 to $11.5 \mathrm{ppm}[17,18]$. In the large urban areas these concentrations could be much higher $[19,20]$. Since the wide range of modelled and measured methane concentrations were reported, modelled concentrations obtained within this study were in the magnitude of reported values. 


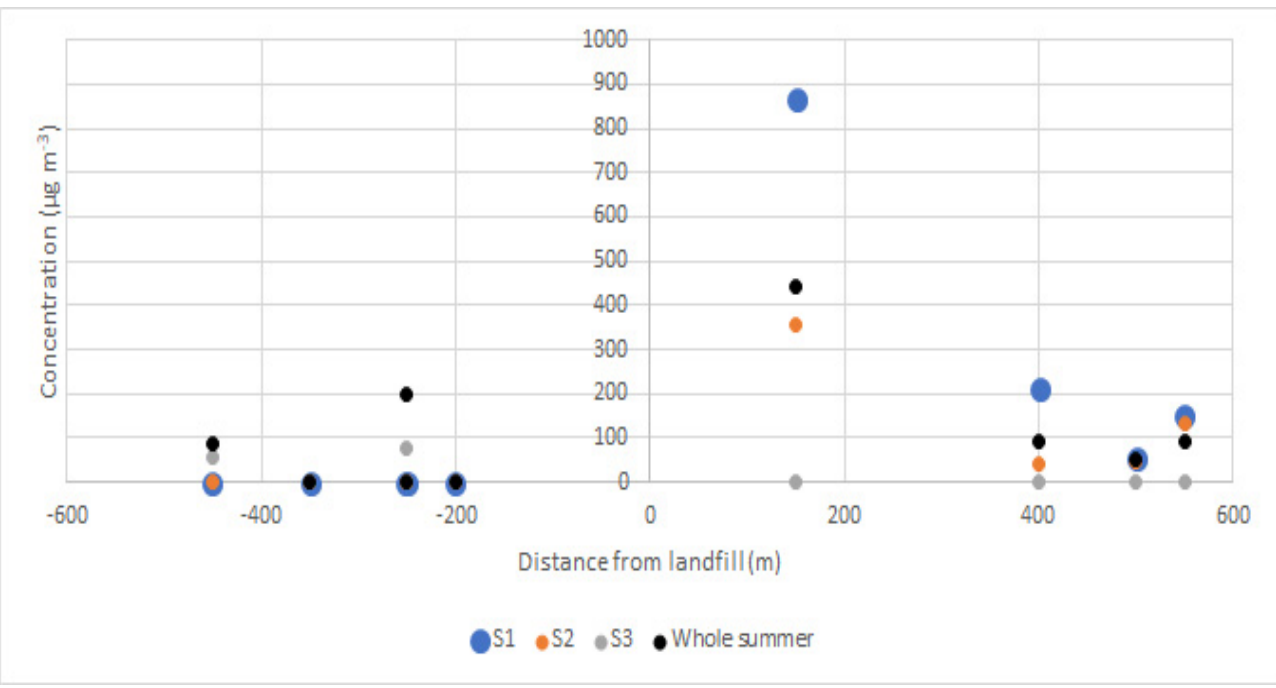

Figure 6. Spatial methane concentration for all scenarios $(\mathrm{H}=0 \mathrm{~m})$. Landfill location is represented at the beginning of the coordinate system (0); Receptor located west and south-west (Industry 1, Industry 2, Houses 1, Houses 2 and Shopping mall) are represented in the left part of chart (negative axis); Receptor located north-east and east form the landfill are located on the right part of the chart (positive axis).

\section{CONCLUSION}

Landfilling is the dominant waste disposal method and there are numerous controlled and uncontrolled waste landfilling activities. In order to minimize human health and environmental risks, these locations require closure and remediation prior to European Union accession. Currently in the Republic of Serbia only methane potential is considered as one of the risk assessments factors prior to landfill closure and remediation. Since the practice of daily covering with soil layer is not well established and the methane generation potential is different at each landfill, the potential risk of the landfill itself is unique too.

This study implies the need of inclusion of methane distribution patterns after emission in the ambient air in the overall landfill closure risk assessment model. Methane fate in the atmosphere is subject of complex processes and depends on physical properties of the environment as well as of the ambience monitoring of methane at certain distances from the source of emission. In combination with the distribution modelling is important for identification of vulnerable area potentially influenced by emitted methane and risk prioritization of specific locations. 
Determination of methane distribution patterns after emissions from the controlled landfill in Novi Sad was carried out in three phases. Since no reliable and measured data on methane emission are available, methane flux was assessed using LandGEM model for methane generation. Representative meteorological data were collected and processed, and three meteorological scenarios were developed to understand and assess the potential influence of methane distribution after its emission in the atmosphere. The modelling of methane distribution in the ambient air was performed using ADMS Urban software. Modelled methane concentration showed different dispersion patterns. Since the entire landfill body is elevated, modelling of methane dispersion did not indicate significant concentrations at the lower atmospheric levels. Methane dispersion improved in higher altitudes due to methane's buoyancy and increasing of the air volume in the mixing layer. Hence, high concentration of methane could not be expected in identified vulnerable areas of Novi Sad. In addition, modelling indicated the potentially unfavorable meteorological conditions which contribute to methane distribution into the air. The risk for population could exist in scenarios with dominant low speed north-east (NE) or east-north-east (ENE) wind, in which the methane dispersion could be expected in directions towards the settlement. However, that is very rare occurrence concerning the dominant wind directions. Maximal concentrations in all investigated scenarios were reached at less than $300 \mathrm{~m}$ from the landfill in direction of the dominant winds.

Models which can generate initial information on methane distribution in the absence of measured data are important to understand and should be included in the overall risk assessment models prior to landfill closure. This research indicates how methane distribution patterns can be assessed if there is no available data and highlights that the methane distribution depending on the terrain and meteorological factors can be important and it should be included as one of the factors in landfill risk assessment models.

\section{EXPERIMENTAL}

Methodological steps presented here provide a roadmap for researchers and waste management stakeholders to develop thorough, data-driven representations of their own case studies.

\section{Landfill description}

Landfill in Novi Sad is controlled, fenced with weigh bridge, daily covered with soil and operated by local municipal waste management company. No bottom liner and no leachate and gas collection system exists. Passive gas 
venting system is constructed to prevent methane accumulation in the landfill body. There are no precise historical data on the first year of its operation. The estimation indicates that landfill started operating between 1960 and 1970 . Today landfill body covers 22 ha and contains approximately $2,000,000 \mathrm{~m}^{3}$. The distance from residential area is $700 \mathrm{~m}$. Landfill depth varies from 3 to $25 \mathrm{~m}$. For modelling, an average landfill height of $17 \mathrm{~m}$ was adopted (personal communications, 2018). The landfill will have been closed by 2025 , when a new sanitary landfill will start operating. The location is presented in Figure 7.

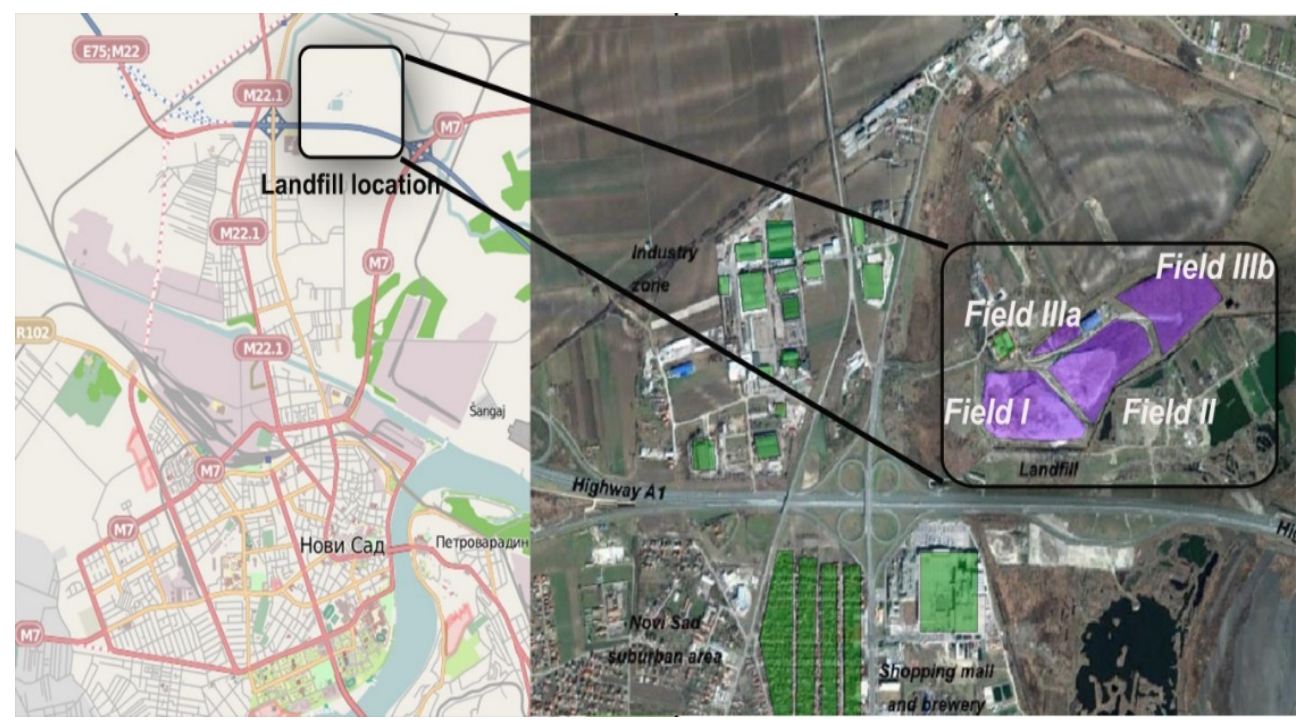

Figure 7. Location of the landfill

\section{Determination of methane distribution in the ambient air}

Simulation of methane distribution in the ambient air was performed by ADMS software. The ADMS is widely used dispersion model which simulates a wide range of pollution from various sources based on Gaussian distribution [14, 21-23]. As an output, ADMS generates short-term, ST (daily and monthly) and long-term, LT (annual) propagation scenarios.

The following data are used as an input for modelling in ADMS:

1. Emission related parameters - Methane emissions are estimated using LandGEM model. This model is a function of two model parameters, methane production potential and first-order decay rate which is associated with waste decomposition $\left(\mathrm{yr}^{-1}\right)$ [24]. The LanGEM is represented by the following equation: 
BOGDANA VUJIĆ, NEMANJA STANISAVLJEVIC, FRANCISC POPESCU, NIKOLINA TOSIC,

UNA MARČETA, MARJANA PARDANJAC, VASILE PODE

$$
Q_{n}=k L_{0} \sum_{i=0}^{n} \sum_{j=0.0}^{0.9} \frac{M_{i}}{10} e^{-k t_{i j}}
$$

where $Q_{n}$ is $\mathrm{CH}_{4}$ generation rate $\left(\mathrm{m}^{3} \mathrm{yr}^{-1}\right)$ in year $\mathrm{n}$; $k$ is first-order waste decay rate $\left(\mathrm{yr}^{-1}\right) ; \mathrm{L}_{0}$ is the $\mathrm{CH}_{4}$ generation potential $\left(\mathrm{m}^{3} \mathrm{Mg}^{-1}\right.$ wet waste); $\mathrm{M}_{\mathrm{i}}$ is the waste mass placement per year $i(\mathrm{Mg})$; $\mathrm{j}$ is and intra-annual time increment used to calculate $\mathrm{CH}_{4}$ generation; and $t$ is time (yr).

Since no gas collection system existed from the initial year of operation, the landfill gas collection efficiency was set to zero. The following values are used for running the LandGem model: $\mathrm{K}=0.040$ year- ${ }^{-1}$, Lo $=100 \mathrm{~m}^{3} \mathrm{Mg}^{-1}$, Methane Content $=50 \%$ by volume. Because the landfill in Novi Sad is daily covered with the soil layer, methane oxidation factor in landfill cover soil is estimated and included in the model. Various $\mathrm{CH}_{4}$ oxidation rates for different cover materials have been reported [25]. For different soil covers, oxidation factors can vary between 0.1 and 0.81 [26], while for compost oxidation in compost reported rates reported are in the range of 0.16 to $0.98[27,28]$. Considering that Novi Sad the landfill in Novi Sad uses daily soil cover, with no data about its performance and efficiency, oxidation factor of 0.1 is applied. Sensitivity analysis is performed with 0.2 and 0.5 oxidation factors as alternate values to assess influence of methane oxidation variation in soil cover.

Waste generation data was developed based on the International Management Group (IMG) [29]. According to the available data Novi Sad generates 120,000 tons of MSW year ${ }^{-1}$. The landfill started receiving waste between 1960 and 1970. Since no data on MSW generation existed at that time, waste generation rate $\mathrm{kg}_{\text {capita-1}} \mathrm{yr}^{-1}$ was used as a constant in order to estimate waste delivery rate from 1960 to 1970. Methane generation modelling is performed using 1960 and 1970 as initial years of waste disposal. The landfill model is set as a volume source of fugitive emissions that are constantly emitted with no significant emission velocity. An average adopted temperature of emitted methane was set up to $30^{\circ} \mathrm{C}$ [30].

2. Meteorological parameters - Methane emissions from the landfill in Novi Sad are negligible during winter period [3]. In order to simulate and assess the most unfavorable scenario, methane distribution is modelled for the summer season when emissions are the most intensive. Hence, meteorological data for summer 2016 were used. Data were analyzed and processed to identify critical meteorological conditions that contributes methane dispersion in the ambient air.

Accordingly, three metrological scenarios were developed: 
- Scenario I (S1) representative for rainy summer period in August: relative low summer temperature $\left(21.4^{\circ} \mathrm{C}\right)$, high relative humidity $(98 \%)$, high cloud cover (8 oktas) and dominant NW wind direction with low speed $\left(2.4 \mathrm{~ms}^{-1}\right)$.

- Scenario II (S2), representative for warm and cloudy period in July: elevated temperature $\left(29.8^{\circ} \mathrm{C}\right)$, low relative humidity $(70 \%)$, high cloud cover (5 oktas) and, dominant NNW wind direction with relative low wind speed $\left(2.4 \mathrm{~ms}^{-1}\right)$.

- Scenario III (S3), representative for hot and windy period in June: elevated temperature $\left(31.8^{\circ} \mathrm{C}\right)$, low relative humidity $(60 \%)$, clear weather (0 oktas), dominant ESE wind speed with high wind speed $\left(9.4 \mathrm{~ms}^{-1}\right)$.

3. Ambient related parameters - In order to simulate vertical and horizontal $\mathrm{CH}_{4}$ dispersion, modelling domain was defined as an area of 1000 $x 1000 \mathrm{~m}(\mathrm{X}, \mathrm{Y})$, with the resolution of 31 points in each direction. The altitude of $50 \mathrm{~m} \mathrm{(Z)} \mathrm{with} 7$ output points for concentrations calculation (at $0,8,17,25$, 33,42 and $50 \mathrm{~m}$ ) have been applied. The simulation of real environment is presented in Figure 8.

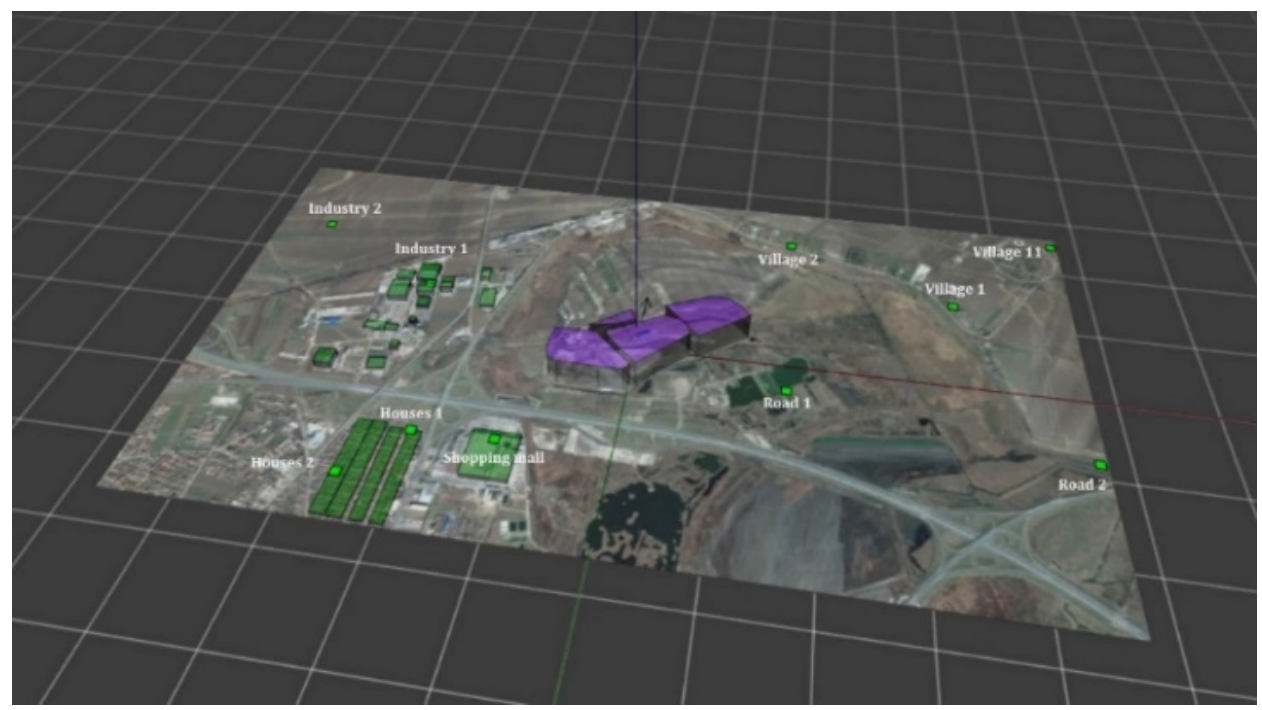

Figure 8. Simulation of the real environment

The specific points (receptors) were defined to quantify spatial methane dispersion from landfill in dominant air flows. Disposition of the receptors are given in Figure 8. Distances from receptors are given in Table 3. 
BOGDANA VUJIĆ, NEMANJA STANISAVLJEVIC, FRANCISC POPESCU, NIKOLINA TOSIC,

UNA MARČETA, MARJANA PARDANJAC, VASILE PODE

Table 3. Specified points description

\begin{tabular}{|c|c|c|}
\hline $\begin{array}{l}\text { Specified } \\
\text { Points }\end{array}$ & $\begin{array}{l}\text { Distance from } \\
\text { the landfill }(\mathrm{m})\end{array}$ & Description \\
\hline Houses 1 & 250 & \multirow{2}{*}{ Suburban area of Novi Sad } \\
\hline Houses 2 & 350 & \\
\hline Shopping mall & 200 & Shopping mall (hypermarket) with brewery \\
\hline Road 1 & 170 & Near road receptor, pasture area \\
\hline Village 1 & 380 & \multirow{2}{*}{ Small settlement, mostly old houses } \\
\hline Village 2 & 280 & \\
\hline Industry 1 & 270 & Commercial entities \\
\hline Industry 2 & 470 & \multirow{3}{*}{$\begin{array}{l}\text { Additional receptor points at the dominant } \\
\text { directions of the methane distribution }\end{array}$} \\
\hline Road 2 & 470 & \\
\hline Village 11 & 530 & \\
\hline
\end{tabular}

The modelling was performed in two iterations with previously described meteorological data sets for the entire testing domain, as well as for specified vulnerable points.

\section{ACKNOWLEDGEMENTS}

This study has received funding from the Provincial Secretariat for Higher Education and Scientific Research, Autonomous Province of Vojvodina, project No. 114-451-2249.

\section{REFERENCES}

1. N. Stanisavljević; D. Ubavin; B. Batinić; J. Fellner; G. Vujić; Waste Management and Research, 2012, 30(10), 1095-1103.

2. SEPA; Serbian Agency for Environmental Protection, 2017, available at: www.sepa.gov.rs, (accessed 16 November 2017).

3. G. Vujic; N. Jovičić; M. Petrović-Djurović; D. Ubavin; B. Nakomčić; G. Jovičić; D. Gordić; Therm. Sci., 2010, 14(2), 555-564.

4. E. Mihajlović; L. Milošević; J. Radosavljević; A. Djordjević; I. Krstić; Therm. Sci., 2016, 20(4), 1295-1305.

5. R. V. Karanjekar; A. Bhatt; S. Altouqui; N. Jangikhatoonabad; V. Durai; M. L. Sattler; M. D. Sahadat Hossain; V. Chen; J. Waste Manag., 2015, 46, 389-398.

6. IPCC, Guidelines for National Greenhouse Gas Inventories, 2006, Volume 5 Waste ISBN 4-88788-032-4. 
INFLUENCE OF LANDFILL METHANE EMISSIONS ON ENVIRONMENT DISTRIBUTION MODELLING AND ASSESSMENT

7. A. Leelossy; Jr. Ferenc Molnár; F. Izsák; A. Havasi; I. Lagzi; R. Mészáros; Centr. Eur. J. Geosci., 2014, 6(3), 257-278.

8. N. S. Holmes; L. Morawska; Atmos. Environ., 2006, 40(30), 5902-5928.

9. D. M. Taylor; F. K. Chow; M. Delkash; P. T. Imhoff; J. Waste Manag., 2018, 73, 197-209.

10. J. G. Mønster; J. Samuelsson; P. Kjeldsen; C. W. Rella; C. Scheutz; J. Waste Manag., 2014, 34(8), 1416-1428.

11. R.J. Cicerone, R.S Oremland; Global Biogeochem. cycles, 1988, 2(4), 299-327.

12. C. G. Nolte; T. L. Spero; J. H. Bowden; M. S. Mallard; P. D. Dolwick; Atmosph. Chem. Phys., 2018, 18(20), 15471-15489.

13. I. Paraskaki; M. Lazaridis; Waste Manag. Res., 2005, 23(3), 199-208.

14. Z. Torok, N. Ajtai, A. Ozunu; Studia UBB Chemia, 2009, LIV1, 49-58

15. M. Á. García; M. L. Sánchez; I. A. Pérez; M. I. Ozores; N. Pardo; Sci.Tot. Environ., 2016, 550, 157-166.

16. A. T. Lando; H. Nakayama; T. Shimaoka; J. Waste Manag., 2017, 59, 255-266.

17.I. Haiduc; M.S. Beldean-Galea; Air Quality - Models and Applications, 2011, INTech, UK, 289-318.

18. C. Cuna; P. Ardelean; S. Cuna; Studia UBB Physica XLVIII, 2003, 565-567.

19. M. Aikawa; T. Hiraki; J. Eiho; Atmos. Environ., 2006, 40(23), 4308-4315.

20. E. Ahmed; K. H. Kim; E. C. Jeon; R. J. C; Sci. Total Environ., 2015, 518-519, 595-604.

21.CERC; ADMS-Urban: Urban Air Quality Management System. User Guide. Version 3.1. 2001, CERC Limited, Cambridge, available at: www.cerc.co.uk, (accessed 14 September 2017).

22. S. E. Belcher; O. Coceal; J. C. R. Hunt; D. J. Carruthers; A. G. Robins; Atmospheric Dispersion Modelling Liaison Committee, ADMLC-R7, 2013

23. B. Vujic; U. Marceta; V. Mihajlovic; A. Djuric; Reciklaza i Odrzivi Razvoj, 2018, 10(1), 9-14.

24. U.S. Environmental Protection Agency: Washington, D.C., Landfill Gas Emissions Model (LandGEM), Version 3.02 User's Guide, 2005, available at: http://www.epa.gov/ ttncatc1/dir1/landgem-v302-guide.pdf, accessed (03 Jun 2018).

25. C. Scheutz; P. Kjeldsen; J. E. Bogner; A. De Visscher; J. Gebert; H. A. Hilger; K. Spokas; Waste Manag. Res., 2009, 27(5), 409-455.

26. R. He; A. Ruan; C. Jiang; D. Shen; Bioresource Technol., 2008, 99(15), 71927199 .

27. J. Berger; L. V. Fornés; C. Ott; J. Jager; B. Wawra; U. Zanke; Waste Manag., 2005, 25(4 SPEC. ISS.), 369-373.

28. R. H. Kettunen; J. K. M. Einola; J. A. Rintala; Water, Air, Soil Pol., 2006, 177(1-4), 313-334.

29. IMG; International Management Group, Saint-Gilles, Belgium: IMG. 2014, available at: www.img-int.org/Central/Public08/, (accessed 17 December 2017).

30. C. Frola; D. De Roze; Solid Waste Association of North America, Sylver Spring, SAD, 1997. 